\title{
PALLD wt Allele
}

National Cancer Institute

\section{Source}

National Cancer Institute. PALLD wt Allele. NCI Thesaurus. Code C79792.

Human PALLD wild-type allele is located in the vicinity of $4 q 32.3$ and is approximately 431 $\mathrm{kb}$ in length. This allele, which encodes palladin protein, plays a role in cellular morphology, motility and adhesion. Genetic variants and aberrant expression are associated with susceptibility to pancreatic cancer type 1 . 